\title{
Pharynx and oesophagus in dystrophia myotonica
}

\author{
J. W. PIERCE, B. CREA MER, AND V. MACDERMOT \\ From St. Thomas's Hospital, London
}

EDITORIAL SYNOPSIS A valuable study is presented of the pharynx and oesophagus in seven cases of dystrophia myotonica. All showed an unusual lesion of weakness of the pharynx, weakness or absence of the cricopharyngeal sphincter, and absence or diminution of oesophageal peristalsis. No evidence was obtained of myotonia in these areas.

Although the manifestations of dystrophia myotonica are widespread, there are few references to involvement of the gastro-intestinal tract. We report here a study of the motility of the pharynx and oesophagus in seven patients, of whom six had some difficulty in swallowing.

\section{CASES}

The clinical picture and results of diagnostic investigation are summarized in Tables I and II. Electromyography was carried out using the technique described by
Bauwens (1955) and the studies on muscle biopsy as described by Coerrs and Woolf (1959). The findings on muscle biopsy have been previously reported by MacDermot (1961).

\section{METHODS}

The intraluminal pressures were measured through fine, water-filled, polythene tubes attached to Hansen capacitance manometers beside the patient. Three tubes were used, fastened at the distal ends, and each recorded through a side hole so spaced that the recording sites

TABLE I

CLINICAL SUMMARIES OF PRESENT SERIES

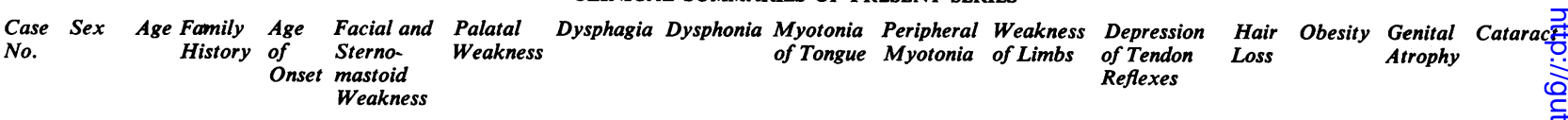

\begin{tabular}{|c|c|c|c|c|c|c|c|c|c|c|c|c|c|c|c|}
\hline $\mathbf{M}$ & 35 & + & 17 & + & + & + & + & 0 & + & + & + & + & + & + & + \\
\hline $\mathbf{M}$ & 58 & 0 & 48 & + & + & + & + & + & + & + & + & + & + & + & + \\
\hline $\mathbf{F}$ & 57 & 0 & 57 & + & 0 & 0 & 0 & 0 & + & 0 & 0 & 0 & 0 & 0 & 0 \\
\hline $\mathbf{F}$ & 58 & 0 & 27 & + & 0 & + & + & 0 & + & + & 0 & + & 0 & 0 & 0 \\
\hline $\mathbf{M}$ & 18 & 0 & 13 & + & 0 & + & 0 & 0 & + & 0 & + & 0 & 0 & 0 & 0 \\
\hline $\mathbf{F}$ & 22 & + & 19 & + & + & + & + & + & + & + & + & 0 & 0 & 0 & 0 \\
\hline $\mathbf{F}$ & 61 & + & 40 & + & + & + & + & 0 & + & + & + & + & 0 & 0 & + \\
\hline
\end{tabular}

TABLE II

ELECTROMYOGRAPHIC AND HISTOLOGICAL EVIDENCE OF INVOLVEMENT OF LIMB MUSCULATURE

Case No. Electromyography of Peripheral Muscles

Muscle Tested Presence of High-

frequency Discharges
Muscle Biopsy

Muscle Tested

d

\begin{tabular}{ll}
$\begin{array}{l}\text { Muscle Fibre } \\
\text { Abnormality (Routine } \\
\text { Stains) }\end{array}$ & $\begin{array}{l}\text { Intramuscular Distal } \\
\text { Nerve Changes } \\
\text { (Methylene Blue) }\end{array}$ \\
\hline
\end{tabular}

\begin{tabular}{ll}
\hline 1 & $\begin{array}{l}\text { Flexor carpi ulnaris. } \\
\text { triceps } \\
\text { Deltoid, brachio- } \\
\text { radialis } \\
\text { Abductor minimi } \\
\text { digiti }\end{array}$ \\
\hline & $\begin{array}{l}\text { Deltoid, extensor } \\
\text { digitorum communis } \\
\text { Abductor pollicis } \\
\text { brevis }\end{array}$ \\
\hline & Deltoid \\
6 & $\begin{array}{l}\text { Extensor carpi ulnaris } \\
\text { extensor carpi radialis }\end{array}$ \\
\hline
\end{tabular}

$\begin{array}{ll}+ & \text { Deltoid } \\ + & \text { Deltoid } \\ + & \text { Deltoid } \\ + & \text { Deltoid } \\ + & \text { Deltoid } \\ + & \text { Deltoid } \\ + & \text { Deltoid }\end{array}$

$\begin{array}{ll}+ & + \\ + & + \\ 0 & + \\ + & + \\ + & + \\ + & +\end{array}$


were $5 \mathrm{~cm}$. apart. Records were taken of the pressures at rest and on swallowing, at various levels in the oesophagus, the cricopharyngeal sphincter, and pharynx.

Radiologically the patients were examined by the conventional barium swallow technique and by cineradiography using a 5 in. Marconi image intensifier. The patients were examined erect and supine while drinking thin barium emulsion. More attention was paid to the appearances of the oesophagus in the supine position, as when erect the effect of gravity tends to overcome any weakness and cases with quite severe degrees of muscular impairment can appear normal.

\section{NORMAL CRITERIA}

PRESSURES At rest the oesophagus is sealed off from the pharynx by a band of increased pressure some $3 \mathrm{~cm}$. in length with a maximum pressure of 30 to $40 \mathrm{~cm}$. of water. This is interpreted as representing the resting tone of the cricopharyngeal sphincter. On swallowing this pressure falls sharply and briefly to intra-oesophageal levels which are a few centimetres of water pressure below atmospheric. Above, in the pharynx, a swift peristaltic wave sweeps downward as the cricopharyngeal sphincter relaxes and in passing through the sphincter closes it. The wave then progresses more slowly down the oesophagus in a propulsive manner.

RADIOLOGY An attempt was made to assess the function of pharynx, cricopharyngeus, and oesophagus separately using the following criteria.

Pharynx The bolus should be passed on quickly and smoothly, without repeated ineffectual contractions. There should be no regurgitation into the nasopharynx when supine.

Cricopharyngeus The sphincter should be seen at rest as an empty segment opening reflexly with every swallow, but at all other times resisting the negative intrathoracic pressure and thus preventing air entering the oesophagus with each inspiration.

Oesophagus There should be no delay in the passage of thin barium; even when supine a few peristaltic waves should empty the oesophagus. The normal oesophagus shows evidence of good stripping waves and does not tolerate the pressure of residual barium or air.

\section{RESULTS}

PRESSURES The overall picture is of weakness from the pharynx to the lower end of the oesophagus (Table III).

At rest the band of pressure separating the pharynx from the oesophagus was markedly diminished in four cases and in one was virtually absent (Fig. 1), similarly the pressure fall on swallowing was less in these cases (Fig. 2). The pressure rise in the pharynx on swallowing was below normal and in only two cases was it seen to be peristaltic. This was due to a complete absence of pressure rise on swallowing in the upper pharynx in these cases.

In the oesophagus a peristaltic sequence was only recorded in one case, and this was of low amplitude. The remaining cases showed a feeble pressure rise that was recorded simultaneously throughout the oesophagus (Fig. 3).

The timing of all pressure changes was normal and no evidence of a prolonged myotonic contraction was found.

RADIOLOGY On present criteria, all patients showed some degree of impaired function (Table IV).

Oesophagus The muscular activity of the oesophagus was abnormal in every case; all showed some delay in the passage of thin barium down the oesophagus into the stomach, but this was not due to any hold-up at the gastro-oesophageal junction. Peristaltic stripping waves were either less frequent, less efficient, or (in three cases) completely absent. Incoordinated non-peristaltic contractions were seen in every patient, and in one (case 8) they were recorded as 'numerous'. In every patient the oesophagus seemed to tolerate residual air or barium for an unduly long time. Whereas in the normal supine

\section{TABLE III}

PRESSURE STUDIES

\begin{tabular}{|c|c|c|c|c|c|c|c|c|}
\hline \multirow[t]{2}{*}{ Case No. } & \multicolumn{3}{|l|}{ Pharynx } & \multicolumn{3}{|c|}{ Cricopharyngeal Sphincter } & \multicolumn{2}{|l|}{ Oesophagus } \\
\hline & $\begin{array}{l}\text { Amplitude of } \\
\text { Wave }(\mathrm{cm} .)\end{array}$ & $\begin{array}{l}\text { Duration of } \\
\text { Wave (sec.) }\end{array}$ & $\begin{array}{l}\text { Peristaltic } \\
\text { Sequence }\end{array}$ & $\begin{array}{l}\text { Resting } \\
\text { Pressure (cm.) }\end{array}$ & $\begin{array}{l}\text { Amplitude of } \\
\text { Relaxation } \\
(\mathrm{cm} .)\end{array}$ & $\begin{array}{l}\text { Duration of } \\
\text { Relaxation } \\
\text { (sec.) }\end{array}$ & $\begin{array}{l}\text { Amplitude of } \\
\text { Wave }(\mathrm{cm} .)\end{array}$ & $\begin{array}{l}\text { Peristaltic } \\
\text { Sequence }\end{array}$ \\
\hline $\begin{array}{c}1 \\
2 \\
3 \\
4 \\
5 \\
6 \\
7 \\
\text { Normal range }\end{array}$ & $\begin{array}{l}+24 \\
+13 \\
+22 \\
+14 \\
+17 \\
+22 \\
+24 \\
+40-+70\end{array}$ & $\begin{array}{l}0.7 \\
0.5 \\
0.7 \\
0.8 \\
0.3 \\
0.5 \\
0.6 \\
0.5-0.9\end{array}$ & $\begin{array}{l}\text { Absent } \\
\text { Absent } \\
\text { Absent } \\
\text { Present } \\
\text { Absent } \\
\text { Absent } \\
\text { Present } \\
\text { Present }\end{array}$ & $\begin{array}{l}+18 \\
+2 \\
+5 \\
+7 \\
+27 \\
+11 \\
+17 \\
+15-+40\end{array}$ & $\begin{array}{l}-15 \\
-4 \\
-4 \\
-6 \\
-27 \\
-12 \\
-20 \\
-15--40\end{array}$ & $\begin{array}{l}0.9 \\
0.5 \\
0.5 \\
0.6 \\
0.6 \\
0.4 \\
0.7 \\
0.5 \cdot 1.0\end{array}$ & $\begin{array}{l}+14 \\
+9 \\
+9 \\
+12 \\
+13 \\
+10 \\
+22 \\
+20-+80\end{array}$ & $\begin{array}{l}\text { Absent } \\
\text { Absent } \\
\text { Present } \\
\text { Absent } \\
\text { Absent } \\
\text { Absent } \\
\text { Absent } \\
\text { Present }\end{array}$ \\
\hline
\end{tabular}




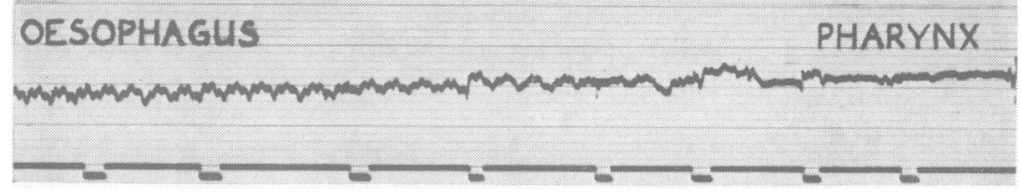

FIG. 1.

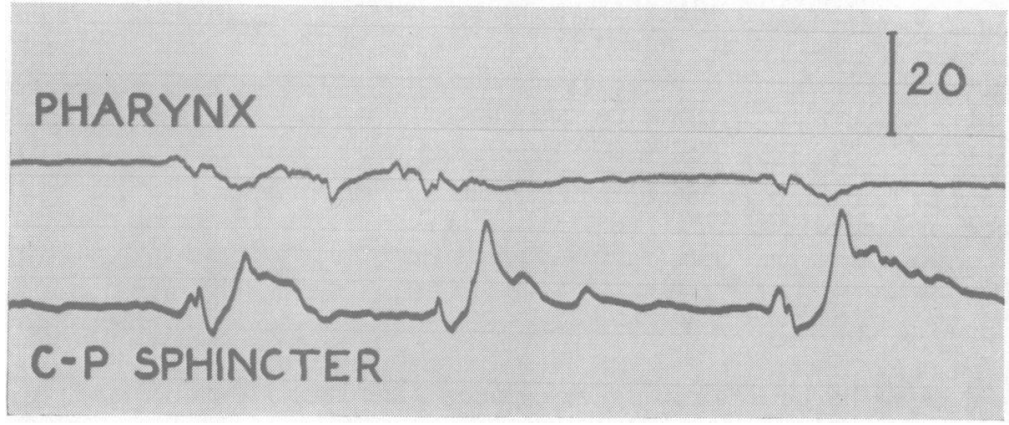

FIG. 2 .

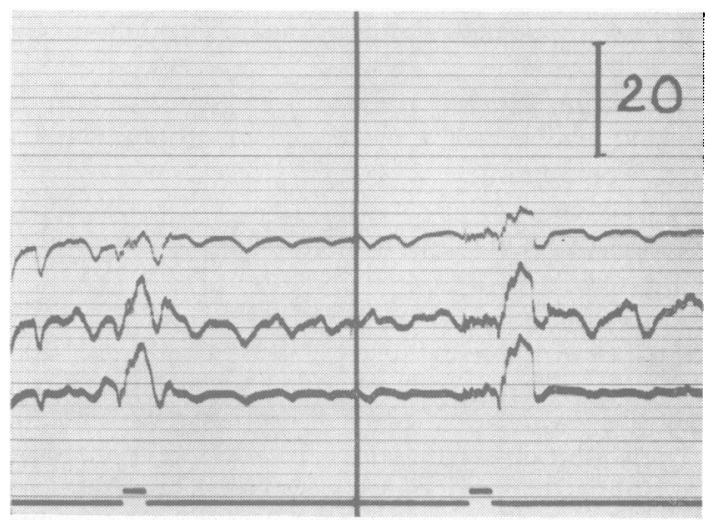

FIG. 3.
FIG. 1. A continuous pressure record as a recording tube is withdrawn at $1 \mathrm{~cm}$. intervals from the oesophagus to the pharynx. The time marker is in seconds and the signal indicates each move of the tube. Note that there is no pressure barrier between the pharynx and the oesophagus.

FIG. 2. A recording from the cricopharyngeal sphincter, bottom trace, and from $5 \mathrm{~cm}$. above in the pharynx, upper trace. Three swallows are shown. The standard is in centimetres of water and the time marker is in seconds. Note that there is no pressure rise in the pharynx on swallowing and a very small fall in pressure $(5 \mathrm{~cm}$. water) in the cricopharyngeal sphincter.

FIG. 3. A recording from the oesophagus using three tubes spaced $5 \mathrm{~cm}$. apart. Two swallow responses are illustrated. There is no evidence of peristalsis and only a small rise of pressure is recorded of simultaneous timing throughout the oesophagus.

TABLE IV

RESULTS OF RADIOLOGY

\begin{tabular}{|c|c|c|c|}
\hline $\begin{array}{l}\text { Case } \\
\text { No. }\end{array}$ & Pharynx & Cricopharyngeus & Oesophagus \\
\hline 1 & Normal & Normal & $\begin{array}{l}\text { Erect: 'normal', no delay, but no evidence } \\
\text { of peristalsis } \\
\text { Supine: definite delay, remains too full } \\
\text { for too long, incoordinated contractions, } \\
\text { but no evidence of true peristalsis }\end{array}$ \\
\hline 2 & $\begin{array}{l}\text { Some difficulty; much effort for small } \\
\text { boluses }\end{array}$ & Partially, if not completely paralysed & $\begin{array}{l}\text { Gross delay; no true peristalsis, but } \\
\text { occasional incoordinate contraction even } \\
\text { obliterating lumen. Appears inert, altering } \\
\text { calibre with respiration }\end{array}$ \\
\hline 5 & Normal & Normal & $\begin{array}{l}\text { Some delay; tolerates residue but can } \\
\text { produce stripping wave and empty }\end{array}$ \\
\hline 7 & $\begin{array}{l}\text { Erect: considerable difficulty; much } \\
\text { effort for small boluses } \\
\text { Supine: free regurgitation up into nose }\end{array}$ & $\begin{array}{l}\text { Can be closed, but can be seen } \\
\text { occasionally open }\end{array}$ & $\begin{array}{l}\text { Marked delay; tolerates residue and air } \\
\text { appears inert, with occasional incoordinate } \\
\text { contractions. No true peristalsis }\end{array}$ \\
\hline 8 & $\begin{array}{l}\text { Probably normal, but? a little } \\
\text { difficulty in passing bolus over back of } \\
\text { tongue }\end{array}$ & Normal & $\begin{array}{l}\text { Definite delay; tolerates residue for too } \\
\text { long; produces numerous incoordinated } \\
\text { contractions but does also show stripping } \\
\text { waves }\end{array}$ \\
\hline
\end{tabular}




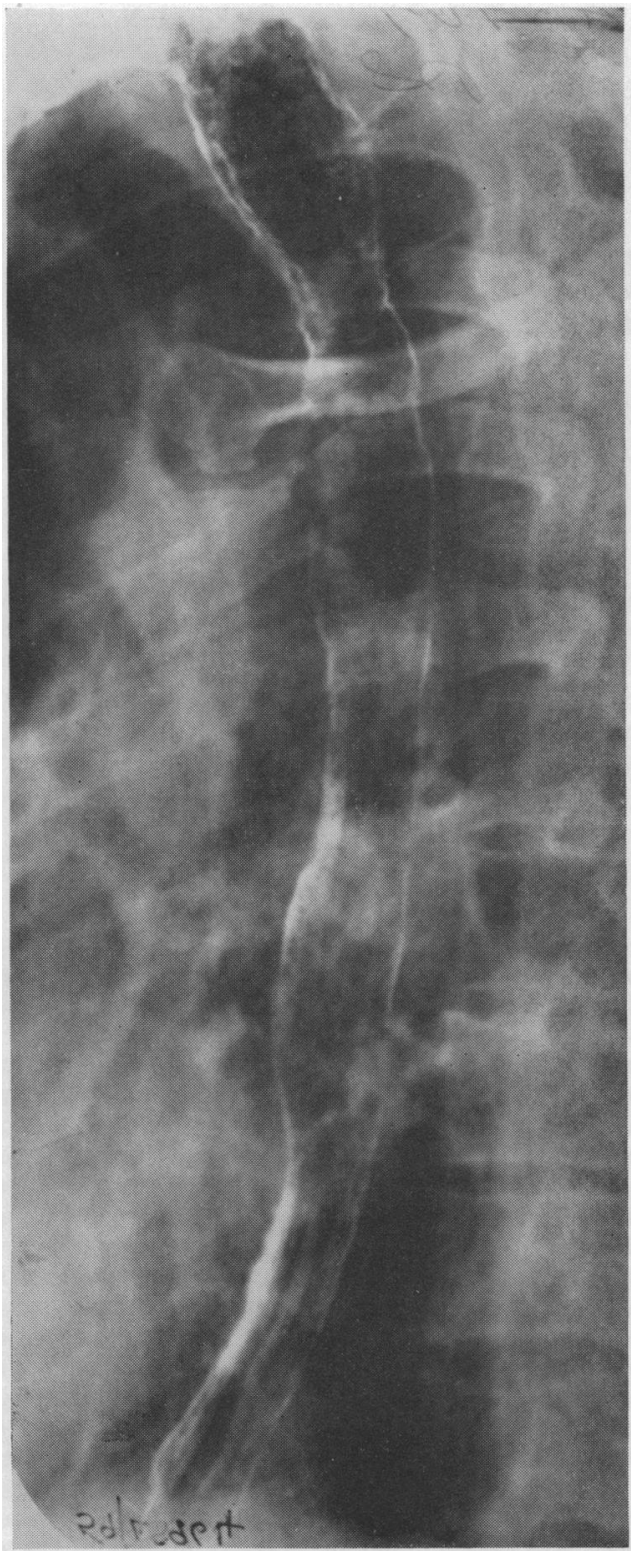

FIG. 4. A radiograph of the barium-coated oesophagus of case 2. The oesophagus is dilated and filled with air with no evidence of activity. On screening, the oesophagus was seen to inflate on inspiration and deflate on expiration.

subject oesophageal distension initiates secondary peristaltic waves which continue until the oesophagus is empty, in these patients this response was either diminished, or in three (cases $1,2,7$ ) absent, the oesophagus remaining full until the patient was returned to the erect position.

Cricopharyngeus In three patients this sphincter was normal; but in one (case 7) it appeared weak, and was sometimes open even when the patient was not swallowing. In case 2 the sphincter was either partially or completely paralysed allowing free passage of air in and out of the oesophagus, which consequently changed size with each respiration.

Pharynx In two patients (cases 1 and 5) the action of the pharynx seemed to be normal; in both the cricopharyngeus was also normal, although the oesophagus was not. Two patients (cases 2 and 7) experienced considerable difficulty in passing a bolus back over the tongue; this was interpreted as evidence of muscular weakness, particularly as in case 2 liquid was freely regurgitated from the pharynx into the nose when the patient was drinking while lying down.

\section{DISCUSSION}

Evidence is presented of gross muscular weakness of the pharynx, cricopharyngeal sphincter, and oesophagus in dystrophia myotonica. When fully developed this presents a unique lesion which we have not seen in other conditions. Radiologically the picture is striking with complete loss of the cricopharyngeal sphincter so that air flows in and out of a flaccid oesophagus on respiration. It is surprising that dysphagia is not more prominent in these patients but inhalation of oesophageal contents leading to pneumonia must be a terminal risk. There is no evidence of myotonia in any of the parts we have examined.

Difficulty in mastication due to facial weakness is often mentioned in the literature but reports of dysphagia are very rare. There are a few pathological descriptions of the oesophagus in cases of progressive muscular dystrophy, though none of these were mentioned as having myotonia, showing oedema, atrophy of muscle, and replacement fibrosis (Bevans, 1945).

We wish to thank Dr. R. E. Kelly for permission to study six of these patients, also the Medical Research Council and the Endowment Fund of St. Thomas's Hospital for financial support for V.M.

\section{REFERENCES}

Bauwens, P. (1955). Electrodiagnosis in motor unit dysfunction. Proc. roy. Soc. Med., 48, 194-200.

Bevans, M. (1945). Changes in the musculature of the gastrointestinal tract and in the myocardium in progressive muscular dystrophy. Arch. Path., 40, 225-238.

Coërs, C., and Woolf A. L. (1959). The Innervation of Muscle, pp. 107-112. Blackwell, Oxford.

MacDermot, V. (1961). The histology of the neuromuscular junction in dystrophia myotonica. Brain, 84, 75-84. 